\title{
Outside the Gates of Europe, the Weapons Speak: Metaphorical Conceptualizations of Ukraine and Russia in German Media Discourse
}

\author{
FELIX KRAUSE \\ Humboldt University of Berlin, Germany \\ felix.krause@gmx.net
}

\begin{abstract}
The world of global politics is composed of complex, interrelated and events. To obtain information, to form an opinion and to react to recent developments, policy makers as well as the public depend on news media. Decisions in the field of global politics, therefore, are based on perceptions and beliefs rather than on objective assessments. The following study takes the example of the German print media, analysing the German perception of Russia and Ukraine within the context of the ongoing Ukraine conflict. The current political development in Ukraine is complex, driven by geopolitical, economical and ideological factors. A mediation of these events by news media therefore requires a drastic reduction of complexity to inform readers and decision-makers on developments in this region. Through examination of conceptual metaphors used in the representation of the conflict, this study seeks to better understand how the two main state actors are comprehended and portrayed in German media discourse.
\end{abstract}

Keywords: global politics, media analysis, German print media, Ukraine, Russia

\section{Introduction}

The world of global politics is composed of highly complex, distant and even contradictory events. To obtain information, to form an opinion and to react to recent developments, policy makers as well as the public depend on news media. Therefore, analysts and academics have assumed that decisions in the field of global politics are not always based on an objective assessment of reality but rather on perceptions and beliefs about the other's "character, intentions, motives and emotions" (Mišík 2013: 446). This is particularly true in conflict situations, where time pressure, uncertainty and competing narratives complicate a constructive analysis.

In this light, the following study turns towards German print media and analyses the German perception of Russia and Ukraine within the context of the ongoing Ukraine conflict. Developments in Ukraine, such as the Euromaidan, the fall of President Yanukovych, and the Russian takeover of Crimea, which quickly escalated into a serious international crisis between Russia, NATO and the European Union (Fischer 2014: 1) have attracted extensive media coverage. This study seeks to better understand how the two main state actors of this conflict are represented and portrayed in German media discourse. In contrast to the dominant methods of German media studies, such as critical discourse analysis (Jäger 2006, 2012) and the sociology 
of knowledge approach to discourse (Keller 2005), this paper aims to add an additional angle to this field by analysing conceptual metaphors. Drawing on Lakoff and Johnson's study (1980), this paper argues that the complexity and uncertainty of events constituting the Ukraine crisis requires concrete and familiar explanatory patterns to enable its communication. By linking the events in Ukraine to more concrete, familiar and intelligible concepts, the media makes the conflict metaphorically understandable, influencing readers' perceptions, opinions and actions.

Analysing a corpus of 50 news articles published in Süddeutsche Zeitung (SZ) between 11 and 31 May 2015, this qualitative study asks how linguistic and conceptional metaphors structure the image of both Ukraine and Russia within the context of the Ukraine crisis. Secondly, I will explore whether there is a dominant pattern in the portrayal of the two countries. Thirdly, I will raise the question of how metaphors used differ from or relate to each other. In closing, I will discuss to what extent a normative evaluation of both actors can be traced back to the way they are conceptualised in the media.

The following sections discuss the theoretical and methodical framework. Afterwards, I present my results, finding that conceptual metaphors play a crucial role in representing Ukraine and Russia within the context of the Ukraine crisis. Particularly metaphors of journey, containers, warfare, of family relations, theatre and health serve to reduce the complexity and construct a relatable image of these distant events. Also, metaphors used imply negative evaluation of both actors. Ukraine, for example, finds itself in asymmetric relationships, such as a patient that needs to be cured or as a student that needs to learn. Russia, on the other hand, is associated with aggressive movements, criminal behavior or hidden intentions.

These insights have far reaching consequences for everyone involved in political opinion and decision making. Although events, such as the Euromaidan, seem to take place whether they are verbalised or not, it is precisely the way we understand and give meaning to these events that influence our reaction. Obviously, conflicts can not be solved by simply changing the language. However, not paying attention to the mutually reinforcing relationship between events and the images used to understand these events may further harden conflict lines and reinforce hostile sentiments. A critical understanding of how our perceptions are shaped by dominant conceptualisations is therefore crucial to engage in a deescalating and peace promoting diplomatic process.

\section{Discourse theory and the study of metaphors}

Empirical discourse studies of German media are dominated by two methodological approaches: sociology of knowledge (Keller 2005; Keller et al. 2006) and critical discourse analysis (Jäger 2006, 2012). Both approaches share a theoretical basis in Michel Foucault's work. Both investigate underlying epistemological structures of discourse that constrain the "thinkable", the "sayable" and the "doable" at a certain historical time and space (cf. Landwehr 2008: 21). They understand language as a system whose structure constitutes a "separate stratum of reality" (Wæver 1996) and distance themselves from a referential understanding of language, in which "words and concepts are names used to refer to objects out there in reality and where therefore the structure and logic of language is to be captured by studying these relationships between words and things" (ibid.: 4). Referring to Ferdinand de Saussure and Claude 
Lévi-Strauss, discourse scholars argue that meaning is constituted within the rules and structure of a language system, in which the ties between the subject and the language are disconnected making language an object of study independent from the subjects using it (Keller 2011: 16). While cognitive linguistics emphasises the role of subjective experiences, analogies and mappings that constitute meaning (cf. Milliken 1999: 235), discourse studies are inherently skeptical towards cognitive or linguistic approaches "that try to use texts to get to what people really thought, and then explain from perception" (Weaver 1996: 4). However, this paper argues that a linguistic approach to conceptual metaphors does not necessarily contradict the structuralist paradigm, but on the contrary, can contribute valuable aspects to the study of discourse.

In their seminal study, Lakoff and Johnson (1980) argue that understanding is widely facilitated through metaphorical concepts. "The essence of metaphor is understanding and experiencing one kind of thing in terms of another" (Lakoff/Johnson 1980: 5). Metaphors structure reality by mapping complex and distant events to more concrete and familiar explanatory patterns taken from the observer's everyday surrounding (ibid.; also Hülsse 2003: 218). On a micro level, this process describes a cognitive model of explaining individual and subjective perception processes. For Lakoff and Johnson, "the human conceptual system is metaphorically structured and defined" (Lakoff/Johnson 1980: 6). Bringing discourse theory and cognitive linguistics together, Hülsse stresses that individually generated metaphors sometimes manage to transcend the individual level. Sometimes, metaphors conventionalise within a society, which gives them the status of entities that circulate within the system of language, which again makes them an interesting subject matter for the analysis of language independent from the subject (cf. Hülsse 2003: 221; Schieder 2016: 8). On a structural level, recurrent metaphors stop being merely subjective cognitive reflexes and therefore tell a lot about the discourse in which they are embedded. It is especially on that structural level that metaphors become invisible, or in other words, "metaphors we live by" (Lakoff/Johnson 1980). Metaphors provide a space of possible and impossible statements that must be used in order to engage in a meaningful conversation (Hülsse 2003: 222). The conventionalisation of metaphors stabilises certain understandings of reality and assures a coherent and uniform discourse by functioning as inter-textual reference (ibid.).

In contrast to empirical discourse analysis, which focuses on substantive content, conceptional metaphor analysis (CMA) looks at the underlying rhetorical and linguistic dimension of reality production (cf. Rodenburg 1998: 35). CMA studies differentiate between the "target" and the "source" of metaphors. The "target" means an "abstract and inherently unstructured subject matter" which is understood by mapping this unknown phenomenon to the "source", a more concrete or more structured subject matter (Grady at al. 1999: 101; Kovecses 2010: 13). This cognitive process of pairing target and source generates a conceptual metaphor. A famous example is the target of the "European Union", a complex political and geographical entity, which often is metaphorically understood through the source of a house or a building.

Secondly, CMA differentiates between conceptual and linguistic metaphors. The conceptual metaphor signifies an underlying concept that gets to the point of a specific target-source relation, but is rarely expressed literally (Bailey 2003: 2). The conceptual metaphor of "Europe is a house" is rarely literally expressed. It is an underlying concept and motivates the use of linguistic metaphors. Linguistic metaphors again are common expressions and practical realisations of the underlying concept. Sayings, such as 
"continuing to build Europe" (Rossmann 2015) or "outside the gates of our Union the weapons speak" (ibid.), refer to an underlying concept of Europe as a house. The concept is understood as a structuring factor predetermining which understanding of reality is privileged. The following analysis of conceptual metaphors will concentrate on identifying such linguistic incidents, clustering them and thereby detecting dominant underlying metaphorical concepts of reality.

The study of perception and metaphors looks back on a rich tradition. In the 1990s, Paul A. Chilton introduced cognitive linguistics to the world of international relations (Chilton 1996; Chilton/Ilyin 1993; see also Schieder 2016: 38). Looking at US security policy during and after the Cold War, he highlights the importance of container metaphors in US security rhetoric. Others followed his path, studying European integration, enlargement and migration (cf. Hülsse 2003: 211; Musolff 2000: 216), as well as Europe's external perception (Chaban et al. 2008; Chaban et al. 2007a; Chaban et al. 2007b; Chaban/Holland 2015). This paper attempts to transfer the analysis of conceptual metaphors to the Ukraine crisis, adding a new angle to the study of images and perception of Ukraine and Russia. I investigated 50 news texts that covered the search word "Ukraine" through a content analysis of the Süddeutsche Zeitung archive (2015). The search word ensured a consistent investigation of all articles that directly report or indirectly include a statement on the situation in Ukraine. The period investigated covers the time from 11 to 31May 2015, when the Eastern Partnership Summit 2015 took place, presenting a spike of reporting on the situation in Eastern Europe.

Closely reading the articles, I collected, clustered and categorised all metaphors used to conceptualise Ukraine and Russia. To structure the research corpus, I used labels that either inductively emerged or that have been proven effective in similar studies (cf. Chaban/Holland 2008: 86f; Chifane 2013: 82). The figures shown in Table 1 list the findings on Ukraine and Russia, contrasted in two columns. Before presenting my findings, I would like to discuss three limitations.

German quality newspapers use concise and factual language to indicate objectiveness and reliability. This seems to suggest that German quality journalism also uses fewer metaphors compared to tabloid newspapers that use sensational language and stereotypical phrases to attract the reader. However, it is important to differentiate between figurative language and metaphors. "A metaphor is not poetical, fanciful, or rhetorical; but it is literal" as Lakoff and Johnson say (1980: 5). In CMA, the very foundation of human language is understood to be metaphorical and often conventionalised to such a degree that people do not recognise those metaphors we live by. In this light, quality newspapers appear especially interesting, since metaphors used in quality journalism can be expected to be more accepted as representing an objective reality.

Secondly, reduction of coverage to the SZ mirrors a restricted view of the media landscape. Other studies have focused on a variety of newspapers representing different political orientations. However, this wider selection was often combined with a shorter time period covered (cf. Schmidt 2016: 72) or a less comprehensive selection of articles (cf. Baltz 2014: 12). It is my interest to uncover metaphorical conventions that stabilise over time, which makes it important to analyze a longer period instead of a variety of sources. As I was interested in "dominant discourses, rather than dissident or idiosyncratic voices” (Mautner 2008: 23), the SZ as the leading nationwide quality 
newspaper presents an obvious and valid source to turn to (Statistica 2015). It covers $84 \%$ of all nationwide quality newspapers sold in Germany during the respective period (SZ n.d.) and is considered the number one newspaper to read by economic and administrative decision makers (Ürük 2016).

Lastly, it often seems that newspaper analysis overemphasises the opinions of journalists and politicians, ignoring a variety of individual opinions that do not have the chance to be published in news media. However, discourse analysis aims to abstract from individual opinion and wants to focus on rules and regularities of what can be meaningfully said in a certain time and space (Landwehr 2008: 21). As an arena of discursive confrontation, it is news media that make public debates visible in the first place and therefore, present one of the most valuable sources for discourse analysis (cf. also Cotter 2015: 430f). Nevertheless, media texts are not a one-way medium that constitute public perceptions (cf. Mautner 2008: 32). News media reflects and reproduces dominant views of society amplifying and reinforcing them at the same time.

\section{Results}

The analysis resulted in a total number of 277 linguistic metaphors almost evenly distributed between Ukraine and Russia with 141 describing the former and 136 the latter. Several underlying conceptual metaphors could be identified. Firstly, orientational metaphors, summarising conceptions of movement and space; secondly, ontological metaphors that represent an abstraction, emotion or idea as something known and concrete, such as containers, persons or objects (cf. Lakoff/Johnson 1980: 25). For example, the abstract entity of the European Union is often understood as a container, more specifically, as a house with doors, walls and neighbors. The most dominant metaphors found fit the categories of movement, space, containers, personifications, war, health and theatre. In the following discussion, examples are translated literally into English to preserve their metaphorical nature. Secondly, the examples are contextualised within miniature narratives that reflect the context of their appearance.

Table 1. Conceptual metaphors according to their instances

\begin{tabular}{|c|c|c|c|c|c|}
\hline Type of Metaphor & Instances & $\%$ & Type of Metaphor & Instances & $\%$ \\
\hline Total N/Ukraine & 141 & $100 \%$ & Total N/Russia & 136 & $100 \%$ \\
\hline Orientational Metaphors & 38 & $27,0 \%$ & Orientational Metaphors & 29 & $21,3 \%$ \\
\hline Down & 6 & $4,3 \%$ & Down & 8 & $5,9 \%$ \\
\hline Up & 1 & $0,7 \%$ & Up & 1 & $0,7 \%$ \\
\hline Slow Pace & 4 & $2,8 \%$ & Slow Pace & 0 & $0,0 \%$ \\
\hline Journey & 11 & $7,8 \%$ & Journey & 9 & $6,6 \%$ \\
\hline Direction of movement & 6 & $4,3 \%$ & Direction of movement & 4 & $2,9 \%$ \\
\hline Localisation in space & 3 & $2,1 \%$ & Localisation in space & 4 & $2,9 \%$ \\
\hline Separation in space & 5 & $3,5 \%$ & Separation in Space & 3 & $2,2 \%$ \\
\hline Expansion in Space & 2 & $1,4 \%$ & Expansion in Space & 0 & $0,0 \%$ \\
\hline $\begin{array}{l}\text { Ontological/structural } \\
\text { Metaphors }\end{array}$ & 103 & $73,0 \%$ & $\begin{array}{l}\text { Ontological/structural } \\
\text { Metaphors }\end{array}$ & 107 & $78,7 \%$ \\
\hline Lack of something & 3 & $2,1 \%$ & Lack of something & 0 & $0,0 \%$ \\
\hline Liquid Substance & 3 & $2,1 \%$ & Liquid Substance & 6 & $4,4 \%$ \\
\hline Expansible Substance & 0 & $0,0 \%$ & Expansible Substance & 2 & $1,5 \%$ \\
\hline Audition & 2 & $1,4 \%$ & Audition & 5 & $3,7 \%$ \\
\hline Vision & 4 & $2,8 \%$ & Vision & 2 & $1,5 \%$ \\
\hline
\end{tabular}




\begin{tabular}{|c|c|c|c|c|c|c|c|}
\hline Temperature & 0 & & $0,0 \%$ & Temperature & 4 & & $2,9 \%$ \\
\hline Container & 28 & & $19,9 \%$ & Container & 5 & & $3,7 \%$ \\
\hline Construction/House & & 15 & $10,6 \%$ & Construction/House & & 4 & $2,9 \%$ \\
\hline residential area & & 6 & $4,3 \%$ & residential area & & 1 & $0,7 \%$ \\
\hline Fragile structure & & 7 & $5,0 \%$ & Fragile substance & 0 & & $0,0 \%$ \\
\hline Personification & 1 & & $0,7 \%$ & Personification & 14 & & $10,3 \%$ \\
\hline Qualities & & 0 & $0,0 \%$ & Qualities & & 3 & $2,2 \%$ \\
\hline Emotions & & 1 & $0,7 \%$ & Emotions & & 11 & $8,1 \%$ \\
\hline Human Relations & 12 & & $8,5 \%$ & Human Relations & 22 & & $16,2 \%$ \\
\hline Friendship & & 3 & $2,1 \%$ & Friendship & & 4 & $2,9 \%$ \\
\hline Partnership & & 1 & $0,7 \%$ & Partnership & & 3 & $2,2 \%$ \\
\hline Family & & 3 & $2,1 \%$ & Family & & 7 & $5,1 \%$ \\
\hline Romantic relations & & 1 & $0,7 \%$ & Romantic relations & & 8 & $5,9 \%$ \\
\hline Teacher-pupil relation & & 3 & $2,1 \%$ & Teacher-pupil relation & & 0 & $0,0 \%$ \\
\hline Religious Community & & 1 & $0,7 \%$ & Religious Community & & 0 & $0,0 \%$ \\
\hline Theatre & 2 & & $1,4 \%$ & Theatre & 10 & & $7,4 \%$ \\
\hline War & 10 & & $7,1 \%$ & War & 9 & & $6,6 \%$ \\
\hline Cleanness & 1 & & $0,7 \%$ & Cleanness & 2 & & $1,5 \%$ \\
\hline Health (poor) & 10 & & $7,1 \%$ & Health (poor) & 2 & & $1,5 \%$ \\
\hline Physics & 7 & & $5,0 \%$ & Physical force & 3 & & $2,2 \%$ \\
\hline Food & 0 & & $0,0 \%$ & Food & 3 & & $2,2 \%$ \\
\hline Violence is Money & 1 & & $0,7 \%$ & Punishment is Money & 4 & & $2,9 \%$ \\
\hline Politic is commodity & 1 & & $0,7 \%$ & Politic is commodity & 0 & & $0,0 \%$ \\
\hline War is conversation & 1 & & $0,7 \%$ & War is conversation & 0 & & $0,0 \%$ \\
\hline Gamble & 1 & & $0,7 \%$ & Gamble & 3 & & $2,2 \%$ \\
\hline Myth & 3 & & $2,1 \%$ & Myth & 1 & & $0,7 \%$ \\
\hline Plant & 6 & & $4,3 \%$ & Plant & 1 & & $0,7 \%$ \\
\hline Temperature & 0 & & $0,0 \%$ & Temperature & 4 & & $2,9 \%$ \\
\hline Machine/Vehicle & 2 & & $1,4 \%$ & Machine/Vehicle & 2 & & $1,5 \%$ \\
\hline Animal & 0 & & $0,0 \%$ & Animal & 3 & & $2,2 \%$ \\
\hline Freedom & 3 & & $2,1 \%$ & Freedom & 0 & & $0,0 \%$ \\
\hline Danger & 2 & & $1,4 \%$ & Danger & 0 & & $0,0 \%$ \\
\hline
\end{tabular}

\subsection{Movement and Space}

\section{Ukraine}

In the case of Ukraine, the most dominant metaphor of movement was the image of a journey. Ukraine was often depicted as being confronted with a variety of paths and distances that had to be overcome or interrupted. For example, Ukraine looks for a "different way" (Hans/Kahlweit 2015) of remembering the 9 May, takes "further steps" (Brössler 2015b) towards the EU, knows the "hurdles" (Kornelius 2015a) of EUintegration, and "bumps" (Brössler 2015b) into resistance from a block of European states countering Ukraine's overhasty integration. The way towards Europe seems to be impeded by another journey Ukraine is urged to stop, namely the 'journey' of corruption. For example, there is hope that the new anti-corruption agency in Ukraine can "turn around" (Kahlweit 2015b) the country. Ukraine is urged to "end" (Kahlweit 2015b) corruption, which appears difficult, since no one knows where the power of oligarchs "start[s] and end[s]" (ibid.). Kiev needs "to go about doing something" (ibid.) against organised crime. Metaphors of Journey are closely linked with metaphors of pace, when President Petro Poroshenko is understood as a "brakesman" (ibid.) in 
fighting corruption, when "no rapid" (SZ 2015b) EU accession is expected or when Ukraine is described "to be stuck in a heavy crisis" (DPA 2015c).

Even though Ukraine seems to be stuck at a crossroads, there is a certain tendency in describing the direction of movement. Much is said about Ukraine's "wishes for convergence" (Kornelius 2015a) with Europe, about the "desire to find protection in the West" (Richter 2015b) and about hopes to "step in" (EU) (Hassel 2015a; SZ 2015b, Brössler 2015b, 2015c, SZ 2015b). This direction is further supported by Europe "luring" (DBR 2015) its Eastern Neighbors with a visa-free regime, or Berlin "attracting" problems in the east "like a magnet does metal chips" (Kornelius 2015c). These two examples, however, come with negative connotations, suggesting an intention by Europe to seduce and, in the second case, an unwanted convergence between Germany and its Eastern Neighbors. Only one metaphor indicated a different orientation, claiming that the tragedy of the Ukrainian conflict lies in the fact that no other "people were as close to the Russians" (Hans 2015b) as the Ukrainians are.

Beside the movement towards the EU, a second movement is the uncontrolled movement downwards. Media reported on the "fall" (Brössler 2015b) of Janukovitsch, on the "fall" (Kahlweit 2015b) of wages and salaries, on the Ukrainian "fall" (Richter 2015a) into the hands of a neighboring nuclear power, on the "deepening" (Brössler 2015c) division between Russia and Ukraine, as well as the "falling apart" (Pantel 2015) of the country.

The most dominant spatial metaphor in reporting on Ukraine within the context of the conflict are separations or exclusions in space. Apart from the deepening "division" (Brössler 2015c) between Ukraine and Russia, Ukraine is described to be "separated" (Hans 2015b) from its 'brother peoples', Ukraine's hopes for EU-integration are "disaggregated" (SZ 2015b), and Ukraine tries to "limit" the power of oil barons (Kahlweit 2015b).

\section{Russia}

In the case of Russia, we find dominant metaphors of movement as well. Putin has "started" an evil game of influence (Kornelius 2015a). The aggression "is sent off" (ibid.) by Russia. "How far will Putin go" (ibid.) in Ukraine? Russia's fight for remembrance "goes on" (Hans/Kahlweit 2015). Russia behaves in a way that does "not" help to "get closer" (Richter 2015b) to the West, and that "leads" towards isolation (Hans 2015b). Closely linked with the metaphor of a journey, Russia is described as moving away and separating itself from the West: it "turns away from Europe" (Augstein 2015) or "takes back" (Hassel 2015b) its sphere of influence. "Russia is not inclined" (Braun/Brössler 2015) towards Europe and is "separated" (Hans 2015b) from its brother Ukraine, moving towards international "isolation" (ibid.). Like Ukraine, Russia is associated with moving downwards. The ruble is described as "fall[ing] in value" (Hans 2015c), Russian exports "drop" (DPA 2015a), and imports "sink" and "shrink" (ibid.). Also, beyond the economic sphere, Russia seems to be associated with downwards movements or operating on a level below the surface. "Fallen" (Wetzel 2015) Russian Soldiers are discussed. The relationship with the USA is at a "low-point" (AFP 2015); it is implied that Russia "undermines" (Kornelius 2015a) Ukrainian society; it operates "under cover" (Hans 2015b) in Ukraine and conducts a "subliminal" hybrid war. Lastly, it "undergirds" (Braun/Brössler 2015) the separatists. 


\subsection{Ontological and structural metaphors}

Spatial orientations and movements provide a "rich basis for understanding concepts in orientational terms" (Lankoff/Johnson: 25). However, further metaphors related to humans' direct experiences with physical objects and substances can be added. This is where ontological and structural metaphors come into play.

\section{Ukraine: A house under construction?}

One of the most dominant metaphors in the case of Ukraine was the metaphor of a fragile structure or a house under construction. Ukraine is struggling for "economic and political stabilisation" (Braun 2015). The Minsk II agreement serves as a "fundament" (ibid.) for this process. Ukraine is in the process of "building" (Kahlweit 2015b) an anti-corruption agency. However, this process remains "fragile" (Braun 2015), the country has problems with "rebuilding" (ibid.) the political system. The country faces the threat of "collapse" (Brössler 2015a), it suffers from "destructive corruption" (Kahlweit 2015b), by which managers of energy companies occupy "key positions" (ibid.), hindering further development. Ukraine is "shaken by many crises" (Braun 2015) and the ceasefire is "breached" (ibid.) almost daily.

The construction work on a fragile structure is often contrasted with the European Union as a stable and highly desired container. Ukraine tries "to find protection in" (Richter 2015b) Europe. Ukraine would like to hear that they are "welcomed" (Brössler 2015b) in Europe. Ukraine is not "in it" (Kornelius 2015a). Ukraine hopes for a perspective for "stepping in" (Brössler 2015c) soon. However, since there is a war "outside the gates of our Union" (Rossmann 2015), the German Government is against a rapid "entry" (SZ 2015b) of Ukraine. Supported by metaphors of construction and houses mentioned above, relations between Europe and Ukraine are often conceptualised as a residential area, for example in talking about Ukraine being the "neighbour" (DBR 2015; Kornelius 2015a; Brössler 2015b) of Europe, or talking about living in the "neighborhood of NATO" (Brössler 2015a).

\section{Ukraine: Personifications and human relations}

Metaphors, personification metonymies play a subordinate role in conceptualising Ukraine in the SZ. A metonymy functions similarly to a metaphorical personification. The difference is, however, that in the case of metonymies, a non-human entity, such as Kiev, Ukraine or the parliament, is used to refer to persons, whereas in the case of personification, human characteristics, behavior or emotional states are used to describe non-human processes or entities (Lakoff/Johnson 1980: 37). In this study, little attention was paid to standard journalistic metonymies only used to avoid repetitions or specifications and without adding personal characteristics, qualities or emotions.

However, a variety of personifications and the use of human relations to describe Ukraine's relationship with other states can be found. The relation between Europe and Ukraine is conceptualised three times either in terms of a friendship or a disappointed friendship (Augstein 2015), for example when it is stated that they are "somehow friends" (Brössler 2015c), that they agree on a partnership that is "supposed to help" (Fried 2015b; Hans/Kahlweit 2015) Ukraine or when Ukraine is depicted as "abandoned by its friends" (Richter 2015a). In three cases, relations between the EU and Ukraine are described as an asymmetric teacher-student relation. Ukraine has to 
"do its homework" (Brössler 2015b), has to "show results" (Kahlweit 2015b) and receives an "admonition" (Braun 2015) from Steinmeier. Relations between Russia and Ukraine, however, are rather described in terms of family relations. Ukraine got separated from its "sister peoples" (Hans 2015b). Ukraine fights against its "big Brother" (Hans/Kahlweit 2015) or "its brother" nation Russia (Brössler 2015c).

\section{Ukraine: War}

Another metaphorical concept applied is that of war. Rhetorically, Ukraine seems to be engaged in several types of war. Firstly, this becomes clear when the German government is said "to fight at the frontline" (Brössler 2015b) against an EU membership perspective of Ukraine. Secondly, the Ukrainian Government does not only fight with weapons against separatists, but also "targets" (Kahlweit 2015c) the east of Ukraine with new laws and tries to find "protection" (Richter 2015b) in Europe. The most frequent war metaphor refers to the "fight against corruption" (Brössler 2015b), which is rhetorically connected with battles against separatists, when at one point President Poroshenko is quoted saying "the front against corruption is as important as the front that our heroes fight at in the east" (Kahlweit 2015b). There is a "struggle of power between different profiteers of corruption" (ibid.). Moreover, Poroshenko "attacks" the oligarch Rinat Akhmetov (ibid.) and there is a description of how bribery helps to "conquer" (ibid.) a job. Lastly, Ukraine needs to "become the master over corruption” (Braun 2015).

\section{Ukraine: Poor Health}

Other metaphors used to conceptualise Ukraine's situation are, for example, of poor health. The country "limps" (Braun 2015), suffers "poor financial health" (DPA 2015b), is "emaciated" (ibid.) from war. Also, corruption in Ukraine is conceptualised as a psychological illness: Oligarchs "suffer kleptomania" (Kahlweit 2015b), like an infection, it is said to be "endemic" (ibid.) and comparable with "cancer" (ibid.). Underlining this, the word "crisis" (e.g. Balser 2015; Fried 2015b; Brössler 2015c), mostly chosen over other possible descriptions, such as the Ukraine conflict, Ukraine disaster or Ukraine war, derives from a medical background, describing a sudden point of change towards a better or worse state of the patient.

\section{Ukraine: Plants and physics}

Metaphors of plants or organic growth and physics have not been as frequent as those expressions mentioned above, but will be mentioned here to complete the picture. The "development" (Pantel 2015) of Ukraine was sometimes depicted as "growth" (Ulrich 2015) of embitterment. The fight against corruption was also conceptualised as "clearing the forest" (Kahlweit 2015b) and bribery was understood as "cutting branches" (ibid.). Lastly, Ukraine was understood as being under the influence of physical forces, such as "pressure" (Brössler 2015a, 2015b) coming from Russia and "magnetic attraction" (Kornelius 2015c) coming from Germany. 


\section{Russia: Personification, emotions and human relations}

In the case of Russia, the dominant metaphor was the personification and the concept of human relations. The complex geostrategic and tactical behavior of Russia is often explained by attributing to Russia, the Russian political elite or Putin emotional motivations or personality traits. For example, Russia claims to be "offended" and "misunderstood" (Richter 2015b) by the West. Russia was "humiliated" (ibid.) after the end of the Cold War; Moscow is "worried" (Pantel 2015) about the situation in Eastern Europe. Germany does not want to "provoke" (Hassel 2015b) the Kremlin. And the Russian author Viktor Jerofejew is quoted saying that it is imperative to "treat Russia finely nuanced" (Augstein 2015). Such personifications interlink with description of Russia acting "aggressively" (Bigalke 2015), causing "aggression" (Kornelius 2015a), acting "criminally" (SZ 2015a) in Crimea and telling a "fairy tale of humiliation" (Richter 2015b), implicitly accusing Russia of not telling the truth.

In addition to such personifications and metonymies, the concept of human relations plays a central role in conceptualising the interaction between Russia and other states. Words used to describe the relationship with the USA and Europe strongly connote with failed partnerships or failed romantic relations. This can be seen in sentences such as "the relationship suffers from misunderstandings" (Richter 2015b), "the relationship got worse" (Bigalke 2015), "they do not come along well anymore" (Hans 2015b) and Greece is "romanced" by two opposing political camps (Kornelius 2015a).

The relation towards Ukraine is again described as a family relation. Beside a variety of cases in which Russia and Ukraine are described as "brothers" (Hans/Kahlweit 2015), Russia can barely afford to pay "alimony" (Augstein 2015) for Crimea. Furthermore, Russian soldiers are depicted as "Russian boys" (Wetzel 2015) and "dead sons" (ibid.) bemoaned by "Russian mothers" (ibid.).

\section{Russia: Theatre}

Metaphors of theatre were prominent in Russia's representation in the news texts. Russia "shows" (Hans/Kahlweit 2015) its armory to the world. Russia has a central "role" (ibid.) in the Ukraine crisis. Russian agents that "played a role" (ibid.) during the annexation of Crimea have been present during the celebrations of 9 May. Borodai "pulled the strings" (ibid.) in Crimea and "performed" a "role" as the first Minister of the People's Republic Donetsk (ibid.). During the celebrations of 9 May, the rocker "applauded fiercely" (ibid.) when Putin paced to his limousine. The annexation of Crimea was not as successful as the political elite may "perform" it (Hans 2015b). Lastly, Eastern Europe is described as a "stage" (Pantel 2015) for the struggle of the East versus the West.

\section{Russia: War}

Metaphors of war were also used frequently. The cooperation between East and West was considered "to have suffered a heavy blow" (SZ 2015a). Moscow is depicted to "capture remembrance" (Hans/Kahlweit 2015). Russia "fights for its position" (Kahlweit 2015c) not to support separatists. It is doubtful whether the "minefield of history" between Poland and Russia can be "cleared" (Hallel 2015). At a congress in Gdańsk, Polish and Russian historians kept "fighting" (ibid.). The "battle" over rightful memory goes on (ibid.); Greece is romanced "by two opposing political camps" (Kornelius 2015a). 


\section{Russia: Containers and liquid substance}

Container metaphors have not been as frequent as those expressions elaborated before, but will once again be mentioned here to complete the picture. They only occurred five times, but all of them in relation to the picture of Europe as a 'house'. Differing from Ukraine, however, Russia was described as being excluded or "locked out" (Kornelius 2015b), and Eastern Europe discussed as "seal[ing] oneself off" against Russian "influence" (Kornelius 2015a). The Author Viktor Jerofejew criticised that in the past, Russia was ignored like a "filthy room" (Augstein 2015). Russian influence was sometimes depicted as a liquid substance, as an "influx" (Kahlweit 2015c) that was coming over Eastern Europe or as an aggression that "dammed up" (Kornelius 2015a) at the eastern border of the European Union.

\section{Discussion of the findings}

A limited set of metaphors is applied when the SZ reports on Ukraine and Russia. In both cases, metaphors of war, journey, personification and human relations were frequent. Ukraine is depicted as being engaged in several wars, namely against Russia, against corruption and for EU integration. Russia, on the other hand, is described as conducting warfare when it defends a historical interpretation or its own point of view. Ukraine is depicted as being stuck at the crossways between two journeys, the journey out of corruption and the journey towards Europe, which is impeded and blocked by some western states. Russia, in contrast, is portrayed as being on a military journey. Ukraine desires a movement towards Europe, but stagnates between East and West. Russia moves away from Europe into isolation. There is surprisingly little personification in the case of Ukraine. Metaphors of human relations describe Ukraine as a country that turned away from its Russian brother/family towards its European partners and friends who, however, do not welcome Ukraine the way it wished. Russia, as well, is depicted as having a 'family' relationship with Ukraine. Its relationship with Europe is pictured as a disappointed friendship and partnership. Personifications depict Russia as a person motivated by hurt feelings. Russia is portrayed as an oversensitive actor, someone who feels insulted or misunderstood. Russia is seen as acting aggressively, in a criminal manner and as telling fairy tales. The most noteworthy differences between the two countries were found in the categories of health and theatre. A variety of medical expressions describe Ukraine as suffering from endemic corruption, evoking a picture of Ukraine as a patient that needs to be cured. One feature of this patient-metaphor is that it highlights a state of powerlessness and innocence that needs to be overcome. At the same time, it hides other aspects. Corruption is a criminal activity driven by human beings that intentionally undermine law and order to gain illicit benefits. Conceptualising corruption as a sickness takes away, to a certain degree, the blame from criminal individuals and failing authorities. Moreover, even though corruption plays big role in Russia, too, Russia is not referred to as a patient needing to be cured. It is rather associated with metaphors of theatre having the "world" watching it. This implies a sense of dishonesty and deception. Someone who "acts" in a theatrical sense does not tell the truth and might pursue hidden agendas.

Another interesting finding is that metaphorical expressions tie in with the widelyinvestigated metaphor of Europe as a house or structure (cf. Chaban et al. 2008: 72; Hülsse 2003: 211; Musolff 2000: 216). The Ukrainian neighbors are conceptualised as being hopeful to enter the European 'house' but, at the same time, lack the required 
stability. Ukraine is depicted as fragile and in need of reconstruction to enter the EU. Russia is metaphorically locked out from the European 'house'. This demonstrates how influential the metaphor of Europe as a house is, structuring political discourse and images of other states far beyond its borders.

Both Ukraine and Russia are largely depicted in a negative light. This reflects tendencies of media products to report on critical or negative events that attract readers' attention (Chaban at. al. 2008: 90). However, negative evaluations differ in nature. Russia is depicted as an aggressor and sometimes as criminal, operating under the surface, "under cover" (Hans 2015b), "subliminal" (Braun/Brössler 2015), "undergirding" (ibid.) and thus is seen as "undermining" (Kornelius 2015a) Ukrainian society. Ukraine, on the other hand, is depicted as being ill, suffering the illness of corruption, unable to win its war on EU-integration and in the east of Ukraine. Ukraine is also pictured as being in an asymmetric relation with Europe: moving towards a skeptical EU and being described as student that has to do itshomework.

\section{Concluding remarks}

The current political development in Ukraine is complex, driven by geopolitical, economical and ideological factors. A mediation of these events by news media therefore requires a drastic reduction of complexity to inform readers and decisionmakers on developments in this region. This study assumed that metaphors play a central role in conceptualising this conflict and therewith reduce its complexity. It was found that news media resort to a limited set of typical metaphorical concepts. Metaphors of war, personifications and metonymy, human relations, health and theater served to conceptualise both countries in a relatable and intelligible way.

Researchers and practitioners in the field of foreign policy need to be aware that decisions and actions are guided by beliefs about the "character, intentions, motivations and emotions" of other states (Mišík 2013: 446). A sensible use and critical stand towards language and the conceptualisation of realty though metaphors is key when assessing complex events of social conflict. As an addition to discourse analysis, CMA presents a valuable tool to analyze external perceptions as well as to get to the bottom of one's own perception of reality, minimising the influence of stereotypes and ideological factors in political decisions. Especially in the case of Europe, Russia and Ukraine, it is important to explore new ways of looking at the world counteracting the relapse into old patterns of perception.

\section{Bibliography}

Baltz, Andre (2014): Through a media lens - The Crimean Crisis. A Discourse Analysis of Media Perspectives on the New Crimean Crisis. Universität Umeå, Faculty of Arts, Department of culture and media studies. Available online at:

http://umu.diva-portal.org/smash/record.jsf?pid=diva2\%3A746908\&dswid=-5275, checked on 2016-03-25.

Chaban, Natalia; Bain, Jessica; Stats, Katrina (2007a): Under Construction. Images of the Enlarging EU in the Australasian News Media. In: Critical Approaches to Discourse Analysis across Disciplines 1 (2), S. 79-95. Available online at: https://digital.library.adelaide.edu.au/dspace/handle/2440/55492. 
Chaban, Natalia; Holland, Martin; Ryan, Peter (2007b): The EU through the eyes of Asia. Singapore, Warsaw, Singapore, Hackensack, NJ: Asia-Europe Foundation; WWZ, Wydzialu Zarzadzania; World Scientific.

Chaban, Natalia; Bain, Jessica; Sutthisripok, Paveena; Choi, Yoon Ah (2008): The European Union in Metaphors. Images of the EU-Enlargement in the Asia-Pacific News. In: Natalia Chaban and Martin Holland (eds.): The European Union and the Asia-Pacific. Media, public, and elite perceptions of the EU. New York: Routledge (6), S. 62-103.

Chaban, Natalia; Holland, Martin (eds.) (2008): The European Union and the AsiaPacific. Media, public, and elite perceptions of the EU. New York: Routledge (6).

Chaban, Natalia; Holland, Martin (2015): EU External Perception: From Innovation to an Established field of study. In: Knud Erik Jørgensen (ed.): The Sage handbook of European foreign policy. Los Angeles: Sage, S. 674-688.

Chifane, Cristina (2013): Metaphors of the Crisis - A Reflection of the Global Financial Situation. In: Management Strategies Journal 22 (4), S. 78-84, checked on 28.03.2016.

Chilton, Paul A. (1996): Security metaphors. Cold war discourse from containment to common house. New York: Lang; P. Lang (vol. 2).

Chilton, Paul A.; Ilyin, Mikhail (1993): Metaphor in Political Discourse: The Case of the 'Common European House'. In: Discourse and Society (4(1)), S. 7-31.

Cotter, Colleen (2015): Discourse and Media. In: Deborah Tannen, Heidi Ehernberger Hamilton and Deborah Schiffrin (eds.): The handbook of discourse analysis. Second edition: Wiley-Blackwell, S. 416-436.

Dollbaum, Jan Matti (2014): Das politische Assoziierungsabkommen zwischen der EU und der Ukraine: Kam die Unterschrift zu früh? Forschungsstelle Osteuropa. Berlin/Mainz (UKRAINE-ANALYSEN, 131). Available online at: www.laenderanalysen.de/ukraine, checked on 2016-03-25.

EPD (2014): Ukraine-Berichterstattung. ZDF-Chefredakteur weist Kritik zurück. ZDF-Chefredakteur Peter Frey weist die Kritik an der Ukraine-Berichterstattung des ZDF zurück. Es sei immer „so objektiv wie möglich“ berichtet worden. In: Frankfurter Allgemeine Zeitung, 27.09.2014. Available online at: http://www.faz.net/aktuell/politik/inland/zdf-chefredakteur-weist-kritik-zurueck13177405.html, checked on 2016-03-24.

Fischer, Sabine (2014): Escalation in Ukraine: conflicting interpretations hamper international diplomacy. Stiftung Wissenschaft und Politik -SWP- German Institute for International and Security Affairs. Berlin (SWP Comments, 17). Available online at: http://nbn-resolving.de/urn:nbn:de:0168-ssoar-388007.

Guzzini, Stefano (2013): The return of geopolitics in Europe? Social mechanisms and foreign policy identity crises ed. by Stefano Guzzini. 1. paperback ed. Cambridge: Cambridge University Press. 
Grady, Joseph E.; Oakley, Todd; Coulson, Seana (1999): Blending and Metaphor. In: Raymond W. Gibbs and Gerard Steen (eds.): Metaphor in cognitive linguistics. Selected papers from the fifth International Cognitive Linguistics Conference, Amsterdam, July 1997. Amsterdam, Philadelphia: J. Benjamins (v. 175), S. 101-124.

Hülsse, Rainer (2003): Sprache ist mehr als Argumentation. Zur wirklichkeitskonstituierenden Rolle von Metaphern. In: Zeitschrift für Internationale Beziehungen 10 (2), S. 211-246.

Jäger, Siegfried (2006): Diskurs und Wissen: Theoretische und methodische Aspekte einer Kritischen Diskurs- und Dispositivanalyse. In: Reiner Keller, Andreas Hirseland, Werner Schneider und Willy Viehöve (eds.): Handbuch sozialwissenschaftliche Diskursanalyse. 2., aktualisierte und erw. Aufl. Wiesbaden: VS-Verl, S. 91-124.

Jäger, Siegfried (2012): Kritische Diskursanalyse. Eine Einführung. 6., vollständig überarb. Aufl. Münster, Westf: Unrast (3).

Kapranov, Oleksandr (2015): Conceptual metaphors in Ukrainian prime ministers' discourse involving renewables. In: Topics in Linguistics (16), S. 4-16, checked on 25.03.2016.

Keller, Reiner (2005): Wissenssoziologische Diskursanalyse. Grundlegung eines Forschungsprogramms. 1. Aufl. Wiesbaden: VS Verlag für Sozialwissenschaften.

Keller, Reiner (2011): Diskursforschung. Eine Einführung für SozialwissenschaftlerInnen. 4. Aufl. Wiesbaden: VS-Verl. (Bd. 14).

Keller, Reiner; Hirseland, Andreas; Schneider, Werner; Viehöve, Willy (eds.) (2006): Handbuch sozialwissenschaftliche Diskursanalyse. 2., aktualisierte und erw. Aufl. Wiesbaden: VS-Verl.

Kovecses, Zoltan (2010): Metaphor. A Practical Introduction. 2nd ed. Oxford, New York: Oxford University Press, USA.

Lakoff, George; Johnson, Mark (1980): Metaphors we live by. Chicago: University of Chicago Press.

Landwehr, Achim (2008): Historische Diskursanalyse. Frankfurt am Main: Campus (4).

Mautner, Gerlinde (2008): Analyzing Newspapers, Magazines and Other Print Media. In: Ruth Wodak and Michał Krzyżanowski (eds.): Qualitative discourse analysis in the social sciences. Houndmills, Basingstoke, Hampshire [England], New York: Palgrave Macmillan, S. 30-53.

Meister, Stefan (2014): Lehren aus der Krise. Die Ukraine, RUssland und die EU. In: Osteuropa 64 (5-6), S. 323-331.

Milliken, Jennifer (1999): The Study of Discourse in International Relations. A Critique of Research and Methods. In: European Journal of International Relations 5 (2), S. 225-254. 
Mišík, Matúš (2013): How can perception help us to understand the dynamic between EU member states? The state of the art. In: Asia Europe Journal December Volume 11 (4), S. 445-463.

Musolff, Andreas (2000): Political Imagery of Europe. A House Without Exit Doors? In: Journal of Multilingual and Multicultural Development 21 (3), S. 216-229.

Rodenburg, Sylvia (1998): Sprachliche Konstruktion der Wirklichkeit. Metaphern in Therapiegesprächen. Wiesbaden: Deutscher Universitätsverlag.

Schieder, Siegfried (2016): Die gestaltende Kraft von Sprachbildern und Metaphern. Deutungen und Konstruktionen von Staatlichkeit in der deutschen Debatte über den europäischen Verfassungsvertrag. Berlin: Springer VS.

Schmidt, Danny (2016): Das Bild Russlands in den deutschen Leitmedien. Die Berichterstattung über Russland und Wladimir Putin im Rahmen der Ukrainekrise. Berlin: Frank et Timme (12).

Staib, Julian (2014): Ukraine-Kommentare im Internet. Meinungsschlacht um die Krim. In: Frankfurter Allgemeine Zeitung, 2014-03-26. Available online at: http://www.faz.net/aktuell/politik/krim-krise-in-deutschen-medien-was-geht-blossin-diesen-koepfen-vor-12865042-p2.html\#/elections, checked on 2016-03-25.

Statistica (2015): Verkaufte Auflage der überregionalen Tageszeitungen in Deutschland im 4. Quartal 2015. Statistica. Das Statistik-Portal. Statistiken und Studien aus über 18.00o Quellen. Start > Branchen > Medien \& Marketing > Verlagswesen \& Buchmarkt >Auflage der überregionalen Tageszeitungen im 4. Quartal 2015. Available online at: http://de.statista.com/statistik/daten/studie/73448/umfrage/auflage-derueberregionalen-tageszeitungen/, checked on 2016-03-25..

SZ (n.d.): Markt- und Medienstudien. Gründe für die Süddeutsche Zeitung. Available online at: http://sz-media.sueddeutsche.de/de/service/markt--und-mediastudienmafo.html, checked on 2016-03-25.

SZ Archive (2015): Innovation. Erfahrung. Wissen. Available online at: www.szarchiv.de/, checked on 2016-03-25.

Ürük, Bülend (2016): Meistzitierte Medien 2015: "Spiegel" vor "Bild" und "Süddeutsche". In: Kreisnews, 2016-01-04. Available online at:

https://kress.de/news/detail/beitrag/133733-meistzitierte-medien-2015-spiegel-vorbild-und-sueddeutsche.html, checked on 25.03.1016.

Vasilaki, Maria (2014): This Revolutionary Situation Has Been Brewing for a Long Time. Metaphors in the Political Speeches about the Ukranian Crisis. In: PARLEY Proceedings - Journal of the Department of Language and Linguistic Science, University of York (2), S. 114-126. Available online at: https://yorkpapersinlinguistics.wordpress.com/parlay-proceedings/parlay-2014proceedings/, checked on 2015-03-25.

Wæver, Ole (1996): Discourse analysis as foreign policy theory. the case of Germany and Europe. Ed. v. University of California at Berkeley. Center for German and 
European Studies (Columbia international affairs online, Working papers). Available online at: http://www.ciaonet.org/wps/waoo1/, checked on 2016-03-24.

Wetzel, Hubert (2015): Ukraine: trotzdem Tod. Meinung. In: Süddeutsche Zeitung No. 122, 2015-05-30, 4 .

\section{List of articles analysed}

AFP (2015a): US-Außenminister in Russland. Politik. In: Süddeutsche Zeitung No. 107, 2015-05-11, 7.

AFP (2015b): Poroschenko: Es ist Krieg. Politik. In: Süddeutsche Zeitung No. 115, 2015-05-21, 7 .

Augstein, Franziska (2015): „Fragen Sie eine Babuschka“. Der russische Schriftsteller Viktor Jerofejew über TV-Zombies in Putins Anhängerschaft, Meinungsfreiheit beim staatlichen Fernsehen und seinen gescheiterten Club für die „Telegenzija“. Medien. In: Süddeutsche Zeitung No. 107, 2015-05-11, 23.

Balser, Marcus (2015): Abrechnung mit Moskau. Enteignete Yukos-Investoren machen ernst: Sie fordern Milliarden und lassen Russlands Staatsvermögen pfänden - bald auch in Deutschland. Wirtschaft. In: Süddeutsche Zeitung No. 116, 2015-05-22, 17 .

Bauchmüller, Michael (2015): Energiewende-Show auf hoher See. Sigmar Gabriel will seinen Amtskollegen aus den wichtigsten Industriestaaten den neuen Windpark vor Helgoland vorführen. Doch die kommen nicht mit. Wirtschaft. In: Süddeutsche Zeitung No. 108, 2015-05-12, 17.

Bigalke, Silke (2015): Nordischer Spagat. Wegen der Spannungen mit Russland bauen Schweden und Finnland Ihre Zusammenarbeit mit der Nato aus. Moskau provozieren wollen sie aber auch nicht. Politik. In: Süddeutsche Zeitung No. 118, 2015-05-26, 15 .

Braun, Stefan (2015): Steinmeiers Sorgen. Außenminister mahnt in Kiew zum Vollzug der Minzker Beschlüsse. Politik. In: Süddeutsche Zeitung No. 122, 2015-0530,7 .

Braun, Stefan; Brössler, Daniel (2015): Mogherini muss das Niet vermeiden. EUAußenbeauftragte braucht Moskaus Rückhalt für ein UN-Mandat gegen Schlepper. Politik. In: Süddeutsche Zeitung No. 109, 2015-05-13, 8.

Brössler, Daniel (2015a): Krisenanrainer. Das Nato-Mitglied Türkei liegt zwischen den Konflikten Ukraine und Irak - nun drängt sie auch ins Zentrum der Allianz. Politik. In: Süddeutsche Zeitung No. 110, 2015-05-15, 6.

Brössler, Daniel (2015b): Geschichte schreiben. Beim Gipfel in Riga wollen die Staats- und Regierungschefs der EU unter Beweis stellen, dass ihre Ostpolitik nicht gescheitert ist - trotz Krim-Annexion und Ukraine-Krieg. Politik. In: Süddeutsche Zeitung No. 115, 2015-05-21, 7. 
Brössler, Daniel (2015c): Doch irgendwie Freunde. Griechenland, Ukraine, abtrünnige Briten: Trotz Krisen endet der Osteuropa-Gipfel in Riga versöhnlich. Politik. In: Süddeutsche Zeitung No. 117, 2015-05-23, 9.

DBR (2015): EU lockt Nachbarn mit Visafreiheit. In: Süddeutsche Zeitung No. 117, 2015-05-23, 1.

DPA (2015a): Russland-Export bricht ein. Wirtschaft. In: Süddeutsche Zeitung No. 116, 2015-05-22, 18.

DPA (2015b): Einreiseverbot in Moskau. Politik. In: Süddeutsche Zeitung No. 118, 2015-05-26, 5 .

DPA (2015c): 915 Millionen Euro für Kiew. Wirtschaft. In: Süddeutsche Zeitung No. 120, 2015-05-28, 19.

DPA (2015d): Ausland. Kredite in Gefahr. Politik. In: Süddeutsche Zeitung No. 121, 2015-05-29, 7.

DPA (2015e): Gazprom fordert Milliarden. Wirtschaft. In: Süddeutsche Zeitung No. 121, 2015-05-29, 20.

DPA, A. F.P. (2015f): Kiew setzt Pflichten aus. Politik. In: Süddeutsche Zeitung No. $116,2015-05-22,6$.

Fried, Nico (2015a): Obamacare. Nur 24 Stunden wird der G-7-Gipfel im Juni dauern - aber im Werdenfelser Land ist deshalb schon seit Monaten die Hölle los. Ein Besuch im "Cultural Hideaway" von Dietmar Müller-Elmau. Und guck mal, wer da mit dem Hubschrauber kommt. Seite Drei. In: Süddeutsche Zeitung No. 111, 2015-05-16, 3.

Fried, Nico (2015b): Schöne Fassade. In Ihrer Regierungserklärung anlässlich des EU-Gipfels dämpft die Kanzlerin die Erwartungen an das G-7-Treffen und versucht, die BND-Krise einfach wegzulächeln - das klappt mal mehr mal weniger gut. Politik. In: Süddeutsche Zeitung No. 116, 2015-05-22, 5.

Fried, Nico; Hickmann, Christoph; Rossmann, Robert (2015): Meine Herren. Gabriel keilt gegen Merkel. Seehofer gegen Gabriel. Und Merkel schweigt sehr, sehr lange. Über ein Trio, dem die schwierigste Phase der Koalition noch bevorsteht. Seite Drei. In: Süddeutsche Zeitung No. 114, 2015-05-20, 3.

Fromm, Thomas (2015): Das „Ja, aber“-Prinzip. Unter dem Skeptiker Norbert Reithofer ist aus BMW in fast neun Jahren ein anderer Konzern geworden. Jetzt wechselt der Chef an die Aufsichtsratsspitze - die Sorgen um die Zukunft bleiben. Wirtschaft. In: Süddeutsche Zeitung No. 107, 2015-05-11, 17.

Gräber, Berrit (2015): Lieber schon zu Hause buchen. Viele Urlauber kümmern sich erst vor Ort um einen Mietwagen. Das kann teuer werden. Wirtschaft. In:

Süddeutsche Zeitung No. 119, 2015-05-27, 27.

Hallel, Florian (2015): Kein Frieden in Danzig. Ein erbitterter Historikerkongress lässt zweifeln, ob die Minenfelder zwischen Polen und Russen überhaupt noch zu räumen sind. Feulleton. In: Süddeutsche Zeitung No. 109, 2015-05-13, 13. 
Hans, Julian (2015a): Deutsch-Russische Beziehungen. Gemeinsame Verantwortung. Meinung. In: Süddeutsche Zeitung No. 107, 2015-05-11, 4.

Hans, Julian (2015b): Bericht: 220 tote russische Soldaten. Nemzow-Vertraute bilanzieren verdeckten Einsatz in der Ukraine. Politik. In: Süddeutsche Zeitung No. 109, 2015-05-13, 8.

Hans, Julian (2015c): USA und Russland gehen vorsichtig aufeinander zu. Kremlchef Putin lotet sein Verhältnis zum Westen aus. Erstmals seit Beginn der Ukraine-Krise tifft er Außenminister Kerry. In: Süddeutsche Zeitung No. 109, 2015-05-13, 1.

Hans, Julian (2015d): Russischer Frühling. Der Verfall des Rubel und des Ölpreises treibt manche Unternehmen in die Pleite, für andere bedeutet er die Rettung. Und er heizt den Immobilienmarkt an. Wirtschaft. In: Süddeutsche Zeitung No. 112, 201505-18, 20.

Hans, Julian (2015e): Russland. Paranoia im Kreml. Meinung. In: Süddeutsche Zeitung No. 115, 2015-05-21, 4.

Hans, Julian; Kahlweit, Cathrin (2015): Parade mit dem Blick zurück. Bei der großen Feier zum 70. Jahrestag des Sieges über Hitler-Deutschland zeigt Russland der sein Arsenal modernster Waffen. Obwohl Kanzlerin Merkel fehlte, sagt Präsident Putin im Kreis seiner Gäste: "Alle, die wir sehen wollten, waren hier". Politik. In: Süddeutsche Zeitung No. 107, 2015-05-11, 7.

Hassel, Florian (2015a): Der Favorit liegt hinten. Überraschung bei Polens Präsidentenwahl - Stichentscheid nötig. Politik. In: Süddeutsche Zeitung No. 107, 2015-05-11, 7 .

Hassel, Florian (2015b): Unerwünschter Luftverkehr. Die baltischen Staaten registrieren über der Ostsee mehr russische Militärjets den je. Weil sie selber zur Überwachung nicht in der Lade sind, hilft eine Mission der Nato. Ein Besuch auf Litaunens Stützpunkt Siauliai. Politik. In: Süddeutsche Zeitung No. 116, 2015-05-22, 7.

Kahlweit, Cathrin (2015a): Schöner Schas. Conchita Wurst und die Folgen: Der Eurovision Songcontest in Wien sprengt schon jetzt alle Grenzen. Gesellschaft. In: Süddeutsche Zeitung No. 111, 2015-05-16, 51.

Kahlweit, Cathrin (2015b): Zahltag in der Ukraine. Korruption ist allgegenwärtig und der Kampf gegen sie undurchsichtig. Doch der Westen will Ergebnisse. Politik. In: Süddeutsche Zeitung No. 111, 2015-05-16, 10.

Kahlweit, Cathrin (2015c): Good bye, Lenin. Die Ukraine verbietet - trotz Kritik kommunistische Symbole. In: Süddeutsche Zeitung No. 112, 2015-05-18, S. 1.

Kornelius, Stefan (2015a): EU und Russland: Nachbar Putin. Meinung. In: Süddeutsche Zeitung No. 116, 2015-05-22, 4.

Kornelius, Stefan (2015b): Mehr als nur ein teures Palaver. Bayern - München. In: Süddeutsche Zeitung No. 117, 2015-05-23, 43. 
Kornelius, Stefan (2015c): In Deckung. Wie steht Deutschland zu den Plänen de Briten? Die EU-Mitglieder hoffen auf ein Signal aus Berlin. Doch Bundeskanzlerin Angela Merkel tut auch in diesem Spannungs-Augenblick das, was sie am besten kann: sie wartet ab. Politik. In: Süddeutsche Zeitung No. 118, 2015-05-26, 6.

Mayer, Verena (2015): Vier Mal "Hochrisiko". Die 65-jähtige Annegret Rauningk hat ihre Vierlinge 15 Wochen zu früh zur Welt gebracht. Die Ärzte sind stolz - und skeptisch. Panorama. In: Süddeutsche Zeitung No. 120, 2015-05-18, 8.

Pantel, Nadia (2015): Der ganze Balkan im Kleinen. Die Auseinandersetzung zwischen Regierung und Opposition in Mazedonien wird schärfer. Zehntausende fordern den Rücktritt von Premier Gruevski. Es wächst die Furcht vor einem Konflikt, der die Nachbarländer mitreißen könnte. Politik. In: Süddeutsche Zeitung No. 112, 2015-05-18, 7 .

Richter, Nicolas (2015a): Saudi-Arabien. Enttäuschte Diktatur. Meinung. In: Süddeutsche Zeitung No. 108, 2015-05-12, 4.

Richter, Nicolas (2015b): USA und Russland. Die Mär der Kränkung. Meinung. In: Süddeutsche Zeitung No. 109, 2015-05-13, 4.

Rossmann, Robert (2015): Apell der Präsidenten. Hollande und Gauck warnen vor Nationalismus in Europa. Politik. In: Süddeutsche Zeitung No. 110, 2015-05-15, 5.

Steinfeld, Thomas (2015): Die Allegorie des Aufschreis. Wer Kritik und Betroffenheit im Rahmen einer Kunstausstellung als Anklage inszeniert, verheddert sich in Widersprüche, die nicht nur das Werk infrage stellen. Feulleton. In: Süddeutsche Zeitung No. 115, 2015-05-21, 11.

SZ (2015a): "Ein Partner und Freund". Putin würdigt Beziehung zu Deutschland trotz Ukraine-Krise. In: Süddeutsche Zeitung No. 107, 2015-05-11, 1.

SZ (2015b): Merkel: Kein rascher EU-Beitritt der Ukraine. In: Süddeutsche Zeitung No. 116, 2015-05-22, 1.

SZ (2015c): Stalin als Heiliger. Feulleton. In: Süddeutsche Zeitung No. 122, 2015-0530,17 .

Ulrich, Stefan (2015): Deutschland und Frankreich: Im Notfall Freunde. Meinung. In: Süddeutsche Zeitung No. 117, 2015-03-23, 4.

Weber, Stefan (2015): "Niemand kauft ein Boot, ohne es zu sehen". Werner Dorsch, Chef der Messe Düsseldorf, über die Konkurrenz im Internet, die Öffnung von Fachausstellungen für ein breites Publikum und den Jahrmarkt der Elternketten. Messewirtschaft. In: Süddeutsche Zeitung No. 119, 2015-05-27, 21.

Wetzel, Hubert (2015): Ukraine: trotzdem Tod. Meinung. In: Süddeutsche Zeitung No. 122, 2015-05-30, 4. 